\title{
$\begin{array}{lllllllll}\mathrm{I} & \mathrm{N} & \mathrm{S} & \mathrm{T} & \mathrm{I} & \mathrm{T} & \mathrm{U} & \mathrm{T} & \mathrm{E}\end{array}$
}

\section{Who Would Be Affected By a New Minimum Wage Policy?}

\author{
JESSICA A. CARSON
}

$\mathrm{I}$ n his February 2013 State of the Union Address, President Obama proposed to increase the federal minimum wage from $\$ 7.25$ to $\$ 9.00$ per hour and to index this increase to inflation. ${ }^{1}$ This proposal, which was designed to support families by promoting a living wage for low-income workers now earning between $\$ 7.25$ and $\$ 9.00,{ }^{2}$ has received mixed feedback, ${ }^{3}$ reflecting decades of contrasting research on the minimum wage. ${ }^{4}$ Although some research finds that increasing the minimum wage could effectively reduce poverty and increase family income,${ }^{5}$ other research suggests that an increase in the minimum wage could result in the loss of low-wage jobs, ${ }^{6}$ or that the wage increase would largely benefit nonpoor families. ${ }^{7}$ Since the President's speech, two related legislative proposals have made it to Congress. Both of these bills aim to raise the minimum wage to $\$ 10.10$ per hour, and both have been referred to congressional committees for further consideration. ${ }^{8}$

What are the characteristics of workers who would be affected by a new minimum wage policy? Because it is unclear whether the proposed legislation will pass in its current incarnation, this brief describes the population who would be directly affected by the President's proposal: workers earning between $\$ 7.25$ and $\$ 9.00$ per hour. Although some research has examined the characteristics of the "minimum wage workforce" (those earning $\$ 7.25$ or less), ${ }^{9}$ there is little known about the population earning the minimum wage or just above (between $\$ 7.25$ and $\$ 9.00$ per hour)..$^{10}$ Using data from the 2010 and 2012 Annual Social and Economic Supplement (ASEC) of the Current Population Survey, ${ }^{11}$ this brief details the characteristics of these potentially affected earners and compares them with the hourly workforce more broadly, paying particular attention to rural-urban differences (see Box 1 on page 4).

It is important to note that, in this sample, about one in three workers who reported being paid hourly did not provide their wage data. Because these missing data are correlated with

\begin{abstract}
Key Findings
- Nearly 17 percent of hourly paid workers earn between $\$ 7.25$ and $\$ 9.00$ per hour and would see a pay increase under the proposed minimum wage policy.

- The increase would disproportionately benefit women, who constitute about one-half of the hourly workforce but 59.4 percent of workers earning between $\$ 7.25$ and $\$ 9.00$ per hour ("affected earners") and a full two-thirds of affected earners in rural places.

- A new policy would disproportionately affect the less educated. While only 11 percent of the hourly workforce lacks a high school diploma, this is true for 25 percent of affected earners in urban places and 19 percent of those in rural places.

- Half of all affected earners are either the householder or the spouse of the householder; the other half are offspring of the householder over age 18 ( 25 percent), children under 18 (5 percent), and other related or unrelated household members (20 percent). Nearly three in ten affected earners ( 29.7 percent) are the sole earner in their family.

- About seven in ten affected earners would see their weekly earnings rise by 10 percent or more, with weekly pay rising an average of 14.9 percent (or about \$45) in rural places and 13.5 percent in urban places (about $\$ 42$ weekly).
\end{abstract}

several demographics (youth, nonwhite race-ethnicity, and lower education), which, in turn, are correlated with lower earnings ${ }^{12}$ it is likely that this brief underestimates the prevalence of affected earners, especially among those populations. 
Some Characteristics Overrepresented Among Affected Earners

Nationwide, 16.5 percent of all hourly workers would be affected by raising the minimum wage from $\$ 7.25$ per hour to $\$ 9.00$ per hour. Table 1 details the demographic characteristics of these potentially affected earners, including comparisons by urbanicity. For instance, women would be disproportionately affected by a rise in the minimum wage; women comprise 50.7 percent of the hourly workforce but 59.4 percent of those who would be affected by a wage increase (Table 1 ). This disparity is even more dramatic in rural places, where women make up two-thirds of affected earners.

Table 1. Demographic Composition of the Affected Earner Workforce and the Hourly Paid Workforce by Place Type

\begin{tabular}{|c|c|c|c|c|c|c|}
\hline & \multicolumn{2}{|c|}{ All Places } & \multicolumn{2}{|c|}{ Urban } & \multicolumn{2}{|c|}{ Rural } \\
\hline & $\begin{array}{c}\text { All Hourly } \\
\text { Paid } \\
\text { Workers }\end{array}$ & $\begin{array}{l}\text { Affected } \\
\text { Earners }\end{array}$ & $\begin{array}{c}\text { All Hourly } \\
\text { Paid } \\
\text { Workers }\end{array}$ & $\begin{array}{c}\text { Affected } \\
\text { Earners }\end{array}$ & $\begin{array}{l}\text { All Hourly } \\
\text { Paid } \\
\text { Workers }\end{array}$ & $\begin{array}{r}\text { Affected } \\
\text { Earners } \\
\end{array}$ \\
\hline $\begin{array}{l}\text { Percent Affected } \\
\text { Place Type }\end{array}$ & 16.5 & - & 16.2 & - & 17.5 & - \\
\hline Urban & 83.0 & 81.9 & - & - & - & - \\
\hline Rural & 17.0 & 18.1 & - & - & - & - \\
\hline Sex & & & & & & \\
\hline Male & 49.3 & $40.6^{*}$ & 49.5 & $42.4 *$ & 48.3 & $33.6 *$ \\
\hline Female & 50.7 & $59.4 *$ & 50.5 & $57.6 *$ & 51.7 & $66.4 *$ \\
\hline Age & & & & & & \\
\hline 15-17 & 1.3 & $5.5 *$ & 1.3 & $5.5 *$ & 1.2 & $4.8 *$ \\
\hline $18-22$ & 12.0 & $30.2 *$ & 11.9 & $30.4 *$ & 12.3 & $29.9 *$ \\
\hline $23-34$ & 27.8 & $27.9 *$ & 28.6 & 28.1 & 23.7 & 26.8 \\
\hline $35-44$ & 17.4 & $10.1^{*}$ & 17.7 & $10.4^{*}$ & 15.8 & $8.5 *$ \\
\hline $45-54$ & 20.8 & $11.7 *$ & 20.6 & $11.5 *$ & 22.4 & $12.9 *$ \\
\hline $55-64$ & 16.2 & $9.9 *$ & 15.6 & $9.3 *$ & 19.1 & $12.5 *$ \\
\hline $65+$ & 4.5 & 4.7 & 4.3 & 4.8 & 5.6 & 4.6 \\
\hline Race & & & & & & \\
\hline White (non-Hispanic) & 71.5 & $63.4^{*}$ & 68.5 & $60.5 *$ & 85.8 & $76.5 *$ \\
\hline Black (non-Hispanic) & 10.2 & $12.8^{*}$ & 11.1 & $13.4^{*}$ & 5.6 & $9.3 *$ \\
\hline Other/Multi (non-Hispanic) & 5.2 & 5.0 & 5.5 & 4.9 & 3.5 & $5.8 *$ \\
\hline Hispanic & 13.2 & $18.8^{*}$ & 14.9 & $21.2 *$ & 5.0 & $8.5 *$ \\
\hline Education & & & & & & \\
\hline Less than high school & 11.0 & $24.1 *$ & 11.1 & $24.9 *$ & 10.2 & $19.3 *$ \\
\hline High school graduate & 35.5 & 34.2 & 33.7 & 32.6 & 44.1 & 41.7 \\
\hline Some college & 35.3 & 34.2 & 35.3 & 34.5 & 35.8 & 33.6 \\
\hline College graduate & 18.2 & $7.5 *$ & 19.9 & $8.0 *$ & 10.0 & $5.4 *$ \\
\hline Marital Status & & & & & & \\
\hline Married & 46.0 & $27.8 *$ & 44.7 & $26.6 *$ & 52.2 & $33.0 *$ \\
\hline Previously married & 16.7 & $13.8^{*}$ & 16.6 & $13.4^{*}$ & 17.8 & $16.2 *$ \\
\hline Never married & 37.3 & $58.4 *$ & 38.8 & $60.0 *$ & 30.1 & $50.8^{*}$ \\
\hline
\end{tabular}

Note: All data are weighted. Asterisks $\left(^{*}\right)$ represent a statistically significant over- or under-representation of each demographic characteristic among affected earners, as compared with the hourly workforce as a whole. 
Younger workers are also disproportionately likely to benefit from the increase. For example, workers aged 18-22 account for more than 30 percent of all affected earners, even though this age group makes up just 12 percent of the hourly workforce. Meanwhile, fewer than 12 percent of potentially affected earners are aged $45-54$, although these workers make up 20.8 percent of the hourly workforce. Finally, 5.5 percent of affected earners are under age 18, higher than their 1.3 percent share of the hourly workforce.

Nonwhite workers are considerably more likely to benefit from the increase than are their white counterparts. For example, non-Hispanic black workers make up 13.4 percent of affected earners in urban places but just 11 percent of the hourly workforce there. In rural places, this relationship is even more pronounced, as 9.3 percent of affected earners are non-Hispanic black, although they account for only 5.6 percent of the rural hourly workforce.

While most affected earners have at least a high school diploma, those without a diploma are overrepresented when compared with the hourly workforce as a whole. Specifically, workers without a high school diploma make up one-fourth of affected earners in urban places and one-fifth in rural places. This means that the majority of affected earners (75.9 percent nationwide) have at least a high school diploma, and 7.5 percent have a four-year college degree or more (see Table 1). However, in the hourly workforce, nearly 90 percent of workers have a high school diploma and 18.2 percent have a four-year degree or more.

Affected earners are most likely to be never married (rather than previously married), with 60 percent of urban affected earners and 50.8 percent of rural affected earners in this group. This is an overrepresentation, as never-married workers make up just 38.8 percent and 30.1 percent of the urban and rural hourly workforces, respectively, and is related in large part to the youth of affected earners. Meanwhile, married workers account for 33 percent of rural affected earners, although they account for more than half of the hourly workforce there. Similar patterns exist within urban areas, with 44.7 percent of the hourly workforce reporting being married and 26.6 percent of affected earners reporting the same.

\section{Affected Earners Are Breadwinners}

As shown in Figure 1, a large proportion of affected earners are householders (that is, the person in whose name the house is rented or owned $)^{13}$ or the spouses of householders. This proportion is higher in rural places, where 56.1 percent of affected earners are the householder or spouse. The remainder of affected earners are offspring of the householder over age 18 (about 25 percent), offspring under age 18 (about 5 percent), and other relatives or nonrelatives of the householder (about 20 percent). ${ }^{14}$
The majority of affected earners do not live with someone else who would be directly affected by the wage increase, and this is even more likely to be true for rural workers (6 percent of rural affected earners live with another affected earner versus 12.2 percent of urban affected earners). However, in both places, about three in ten affected earners are the sole earners in their family, and more than 30 percent of affected earners have children (see Figure 1). Thus, though not a family-level policy, it is clear that a wage increase would have implications for workers' families more broadly.

Figure 1. Percent of Affected earners who...

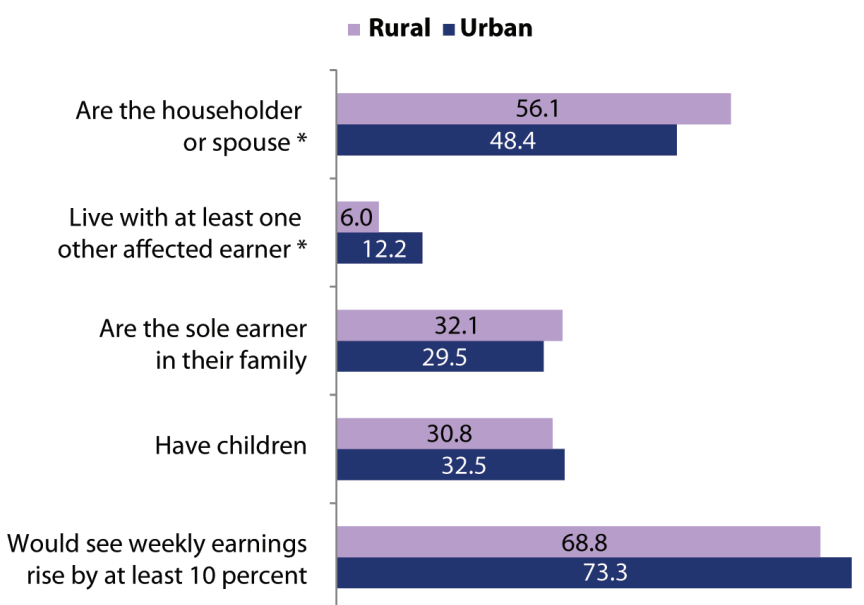

Note: Asterisks denote statistically significant differences between urban and rural places $(p<0.05)$. The characteristic "sole earner in their family" refers only to affected earners who live with at least one other person.

Source: Current Population Survey, Annual Social and Economic Supplement, 2010 \& 2012

Finally, of affected earners in both urban and rural places, about seven in ten would see their weekly earnings rise by 10 percent or more, assuming a 40-hour workweek (see Figure 1). Those in rural places would see a slightly larger increase, with weekly pay rising by an average of 14.9 percent (or about $\$ 45)$, compared with an average increase of 13.5 percent in urban places (about $\$ 42$ weekly).

\section{Policy Implications}

On March 5, 2013, Senator Tom Harkin introduced the Fair Minimum Wage Act (S. 460) to incrementally increase the federal minimum wage to $\$ 10.10$ per hour, ${ }^{15}$ and thereafter index it to inflation, and on March 6, Representative George Miller introduced companion legislation in the House (H.R. 1010). Both bills have been referred to congressional committees and are awaiting further review. ${ }^{16}$ On March 15, 2013, House Republicans voted against a proposal to increase the federal minimum wage to $\$ 10.10$ per hour as an amendment to an act designed to consolidate federal job training programs. ${ }^{17}$ 
Given the current focus on the federal deficit and the limited resources available for direct federal investment in low-income families, raising the minimum wage is one way that Congress might promote stability for those at the bottom end of the wage scale, without relying on federal funds or facing a choice between cutting other programs and increasing the deficit. Of course, to minimize potentially negative employment effects, any minimum wage legislation should be crafted with careful consideration of the implications that an increase may have for firms employing hourly workers. In any case, having an understanding of who these workers are-disproportionately young, female, nonwhite, never married, and less educated-and how their wages fit into the broader context of their families' lives can help to inform these policy decisions.

Box 1: Definition of the Terms Rural and Urban

Definitions of rural and urban vary among researchers and the sources of data they use. Data for this brief come from the Current Population Survey, which indicates whether or not each household is located in a metropolitan area. The Office of Management and Budget defines a metropolitan area as: (1) a central county (or counties) containing at least one urbanized area with a population of at least 50,000 people, and (2) the counties that are socially and economically integrated with the urbanized area, as measured by commuting patterns. In this brief, urban refers to such metropolitan places, and rural refers to nonmetropolitan places outside these boundaries.

\section{Data}

This analysis is based on U.S. Census Bureau estimates from the 2010 and 2012 Annual Social and Economic Supplement (ASEC) of the Current Population Survey. These nonconsecutive survey years were selected in order to maximize the sample size of this project while avoiding the issue of duplicate respondents in consecutive years (up to half of 2012 ASEC respondents also appear in the 2011 ASEC), a strategy that was recommended by the Demographic Surveys Division at the U.S. Census Bureau. Of course, it is possible that the postrecession climate of 2010 had a unique impact on the labor market at that time and that these results may differ slightly from those drawn from a smaller sample that pools 2011 and 2012 data; however, additional analyses using 2012 data alone (not shown) vary little from those shown here in the brief (patterns are identical, though some small shifts in percentages are revealed), and about 16 percent of hourly earners are affected regardless of the data set used. These estimates are meant to give perspective on the characteristics of potentially affected earners; however, because they are based on survey data, one should use caution when comparing across categories, as the margins of error may place seemingly disparate estimates within reasonable sampling error. All differences highlighted in this brief are statistically significant $(p<0.05)$.

\section{E N D N O T E S}

1. "Fact Sheet: The President's Plan to Reward Work by Raising the Minimum Wage" (Washington, DC: Office of the Press Secretary, The White House, 2013), available at www. whitehouse.gov/the-press-office/2013/02/13/fact-sheetpresident-s-plan-reward-work-raising-minimum-wage (retrieved March 25, 2013).

2. Annie Lowrey, "Raising Minimum Wage Would Ease Income Gap but Carries Political Risks," New York Times, February 13, 2013, available at www.nytimes.com/2013/02/13/ us/politics/obama-pushes-for-increase-in-federal-minimum-wage.html?_r=0 (retrieved March 25, 2013).

3. See, for example, Mark J. Perry, "Let's Review the Adverse Effects of Raising the Minimum Wage on Teenagers When It Increased 41\% Between 2007 and 2009" (Washington, DC: American Enterprise Institute, 2013), available at www.aeiideas.org/2013/02/lets-review-the-adverse-effects-of-raisingthe-minimum-wage-on-teenagers-when-it-increased-41-between-2007-and-2009/ (retrieved March 25, 2013); Peter Dreier and Donald Cohen, "Raising the Minimum Wage Is Good For Business (But the Corporate Lobby Doesn't Think So)," Huffington Post, February 23, 2013, available at www.huffingtonpost. com/peter-dreier/raising-the-minimum-wage-_b_2750336. html (retrieved March 25, 2013); Robert Taylor, “Obama’s \$9 Minimum Wage Increase Would Seriously Harm Poor People's Chances of Getting a Job," Policymic Blog, February 2013, available at www.policymic.com/articles/26956/obama-s-9-minimum-wage-increase-would-seriously-harm-poor-people-schances-of-getting-a-job (retrieved March 25, 2013).

4. For a review of some of these mixed findings, see John Schmitt, "Why Does the Minimum Wage Have No Discernible Effect on Employment?" (Washington, DC: Center for Economic and Policy Research, 2013), available at www. cepr.net/documents/publications/min-wage-2013-02.pdf (retrieved April 17, 2013).

5. Ronald B. Mincy, "Raising the Minimum Wage: Effects on Family Poverty," Monthly Labor Review, vol. 113, no. 7 (1990): 18-25; Paul Wolfson and Dale Belman, “The Minimum Wage: Consequences for Prices and Quantities in Low-Wage Labor Markets," Working Paper No. 03-20 (Hanover, NH: Tuck School of Business at Dartmouth), available at papers.ssrn.com/sol3/ papers.cfm?abstract_id=406640 (retrieved April 22, 2013). 
6. Joseph J. Sabia and Richard V. Burkhauser, "Minimum Wages and Poverty: Will a \$9.50 Federal Minimum Wage Really Help the Working Poor?" Southern Economic Journal, vol. 76, no. 3 (2010): 592-623; David Neumark and William Wascher, "Do Minimum Wages Fight Poverty," NBER Working Paper Series No. 6127 (Cambridge, MA: National Bureau of Economic Research), available at www.nber.org/papers/ w6127.pdf?new_window=1 (retrieved April 22, 2013).

7. John P. Formby, John A. Bishop, and Hoseong Kim, “The Redistributive Effects and Cost-Effectiveness of Increasing the Federal Minimum Wage," Public Finance Review, vol. 38, no. 5 (2010): 585-618; Richard V. Burkhauser and Joseph J. Sabia, "The Effectiveness of Minimum-Wage Increases in Reducing Poverty: Past, Present and Future," Contemporary Economic Policy, vol. 25, no. 2 (2007): 262-281.

8. See “S. 460: Fair Minimum Wage Act of 2013," 113th Congress, 2013-2015, March 5, 2013, available at www.govtrack. us/congress/bills/113/s460/text (retrieved April 22, 2013), and "H.R. 1010: Fair Minimum Wage Act of 2013," 113th Congress, 2013-2015, March 6, 2013, available at www.govtrack. us/congress/bills/113/hr1010/text (retrieved April 22, 2013).

9. Note that workers may earn less than $\$ 7.25$ per hour if they are exempt from minimum wage requirements. Exempt occupations include commissioned service workers (for example, restaurant servers), some care-workers (such as companions for the elderly and babysitters), and seasonal/recreational employees (for example, summer camp counselors). For a more complete listing of exemptions to U.S. labor laws, see "Fair Labor Standards Act Advisor-Exemptions" (Washington, DC: U.S. Department of Labor, 2012), available at www. dol.gov/elaws/esa/flsa/screen75.asp (retrieved May 22, 2013). For more on the population earning minimum wage or less, see, for example, "Characteristics of Minimum Wage Workers: 2011” (Washington, DC: Bureau of Labor Statistics, U.S. Department of Labor, 2012), available at www.bls.gov/cps/ minwage2011.pdf (retrieved March 25, 2013).

10. For one piece that has focused on this population, see David Cooper and Doug Hall, "Raising the Federal Minimum Wage to $\$ 10.10$ Would Give Working Families, and the Overall Economy, a Much-Needed Boost," EPI Briefing Paper \#357 (Washington, DC: Economic Policy Institute, 2013), available at www.epi.org/publication/bp357-federalminimum-wage-increase/ (retrieved April 1, 2013).

11. See "Data" section for rationale regarding the use of two nonconsecutive years of data.
12. "Earnings by Age and Sex, Third Quarter of 2010," TED: The Editor's Desk (Washington, DC: Bureau of Labor Statistics, U.S. Department of Labor, 2010), available at www.bls. gov/opub/ted/2010/ted_20101025.htm (retrieved March 25, 2013); “Highlights of Women's Earnings in 2011," Report 1038 (Washington, DC: Bureau of Labor Statistics, U.S. Department of Labor, 2012), available at www.bls.gov/cps/cpswom 2011. pdf (retrieved March 25, 2013); "Education Pays...," Employment Projections (Washington, DC: Bureau of Labor Statistics, U.S. Department of Labor, 2013), available at www.bls.gov/ emp/ep_chart_001.htm (retrieved March 25, 2013).

13. See "Current Population Survey (CPS)_Definitions" (Washington, DC: U.S. Census Bureau, 2013), available at www. census.gov/cps/about/cpsdef.html (retrieved April 25, 2013).

14. Also note that households with at least one affected earner tend to have younger householders than do households nationwide; for example, one in ten affected households is headed by a person under the age of 23, compared to less than 3 percent of households nationwide. Carsey Institute analysis of ASEC data; available upon request.

15. S. 460: Fair Minimum Wage Act of 2013.

16. H.R. 1010: Fair Minimum Wage Act of 2013.

17. Will Wrigley, "House Republicans Unanimously Vote Down Minimum Wage Increase," Huffington Post, March 15, 2013, available at www.huffingtonpost.com/2013/03/15/ gop-minimum-wage-increase_n_2884912.html (retrieved March 25, 2013).

\section{ABOUT THE AUTHOR}

Jessica A. Carson is a vulnerable families research scientist at the Carsey Institute. (jessica.carson@unh.edu).

\section{A C K N O W L E D G E M E N T S}

The author would like to thank Bruce Mallory, Curt Grimm, Beth Mattingly, Amy Sterndale, and Laurel Lloyd at the Carsey Institute for their helpful comments and suggestions; Barbara Ray at Hiredpen, Inc. for editorial assistance; and Andrew Schaefer and Jennifer Clayton at the Carsey Institute for assistance in preparing the data. Special thanks to Kristin Smith of the Carsey Institute and Karen Conway of the University of New Hampshire for their thoughtful feedback on an earlier draft. 


\section{$\triangle$ UNIVERSITY - of NEW HAMPSHIRE}

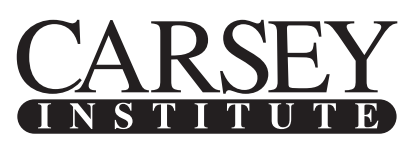

Building knowledge for families and communities

The Carsey Institute conducts policy research on vulnerable children, youth, and families and on sustainable community development. We give policy makers and practitioners timely, independent resources to effect change in their communities.

This work was supported by the Annie E. Casey Foundation, the W. K. Kellogg Foundation, and anonymous donors.

Huddleston Hall

73 Main Street

Durham, NH 03824

(603) $862-2821$

www.carseyinstitute.unh.edu 